\title{
The Ability To Understand Mathematical Concept Of Students Through Cooperative Learning Model Type Of Group Investigation
}

\author{
Zulhendri $^{1)}$, Ambiyar ${ }^{2 *}$, Ishak Aziz ${ }^{3)}$ \\ 1,2,3) Program Studi Doktor Ilmu Pendidikan Pascasarjana Universitas Negeri Padang \\ *Corresponding author \\ Email:zulhendripoenya@gmail.com
}

\begin{abstract}
This studied aims to know whether there was any significant effect ability of understanding mathematical concepts between students using cooperative learning model of Group Investigation (GI) type with students using conventional learning or not in SMP Negeri 3 Pekanbaru. This research was a quasi-experiment; the researcher played a direct role as a teacher in the learning process. Subjects in this study were the eighth grade students of SMP Negeri 3 Pekanbaru, amounting to 66 and the object of this study was an ability of understanding mathematical concepts. Methods used to collect the data of this study were observation, documentation, and testing. In this study, the class meetings were held for six times, one meeting was for a pre test, in which four times of the meeting was carried out with Cooperative Learning model of Group Investigation (GI) type and one meeting was for a post test. The data collected were analyzed using a t test. Based on the analysis of data, it is shown that there are differences in the ability of understanding mathematical concepts between students using cooperative learning model of Group Investigation (GI) type and students using conventional learning in SMP Negeri 3 Pekanbaru. It can be seen from the comparison of to and $\mathrm{t}$. At the level of 5\%, it was indicated that to is more than $\mathrm{tt}$ (3.34 > 2.02). Thus it can be concluded that there were significant effect between students using cooperative learning model of Group Investigation (GI) type with students using conventional learning.
\end{abstract}

Keywords: Cooperative learning, Group Investigation (GI), Understanding Mathematical Concepts

\section{INTRODUCTION}

Mathematics is a subject that exists in every level of education, from elementary school to college. Mathematics is the craft of creating new knowledge from old, using deductive logic and abstraction. Mathematics provides an effective way of building mental discipline and encourages logical reasoning and mental rigor. In addition, mathematical knowledge plays a crucial role in understanding the contents of other school subjects such as science, social studies, and even music and art. The theory of formal patterns. Mathematics is the study of quantity. A discipline that includes the natural numbers and plane and solid geometry.. The rapid development in the information and communication technology is based on the development of mathematics in the fields of number theory, algebra, analysis, probability 
theory, and discrete mathematics. To master and create technology in the future requires a strong mastery of mathematics from an early age.

One of the problems that often arise in learning mathematics is the low ability of students to solve mathematical problems in the form of questions that emphasize understanding concepts in a particular subject. Students who have understood the concept well in the learning process are possible to have high learning achievement because it is easier to follow the lesson while students who do not understand the concept tend to be more difficult to follow the lesson. The low ability of students in the aspect of understanding concepts is an important thing that must be followed up. Regarding the importance of understanding mathematical concepts, the researchers conducted observations, interviews, and saw the documentation of the exercises and the results of students' tests on the previous material.

The lessons build upon the mathematical knowledge and understanding students already have. It is essential that students see the mathematics lesson as an extension or reconstruction of what they already know. This can lead to some principles, theory and practice of skills to support that theory. Then, as mathematical ideas are used by students in decision making and in critical thinking within new contexts, they become integrated as part of the student's knowledge and skill set. This emphasis on actual thinking about the real world makes the mathematics very important to the students, rather than something that they must do. Throughout the process of teaching mathematics, teachers help students make connections with the world they experience around them, and their current and future roles and responsibilities as the students. The understanding of mathematical concepts of class VII students is not so good which can be seen from the problems: Students cannot solve problems that are different from the examples, students only memorize formulas but do not know the meaning, students forget about the material that has been studied even though the material is related, and students have not been able to apply the concept of lessons into their lives. One of the improvement efforts in the learning process is by applying an appropriate strategy or learning model and can improve students' understanding of mathematical concepts.

Next, The most common problem while learning math is that students lack an understanding of the basic concepts. Think of math as building blocks, you need to first lay the foundation before moving forward. And if the foundation is not laid properly, the blocks will fall apart. Similarly, only if your students have a clear understanding of the basics, they'll be able to move ahead in class. For eg. to reduce fractions, students need to know division and to solve linear equations they need to be thorough with arithmetic processes. Many students also find it uncomfortable to admit their difficulty with a certain topic in the class while the teacher has moved to the next lesson. This is the main reason why students start to lag behind in class. Then, teachers should lean towards methods of teaching that are easy to comprehend. But more often than not, the techniques, steps, and formulas taught are not only difficult to understand but also to apply in the real world. If students struggle with grasping a certain method, they will not be able to remember it after class. It is important in this case, that teachers modify their method of teaching to suit the entire class.

Considering the facts above, there would be a need to implement a proper strategy in order to make the students interest in math. There are many alternatives strategies to improve the student's ability in math. One of the strategies that a teacher could use is group investigation. Based on the problems above, the researcher interested to conduct a research 
with the title: "the ability of understanding mathematical concepts of students of grade VII SMPN 3 through cooperative learning model of Group Investigation (GI) type”.

\section{RESEARCH METHODS}

This type of research is a quasi-experimental where the researcher acts directly as a teacher in the learning process. The subjects in this study were 66 students of class VII SMP Negeri 3 Pekanbaru and the object of this research was the ability to understand mathematical concepts with class VII C as the experimental class and class VII D as the control class. The design used was a Randomized Pretest-Posttest Control Group Design. The design of this research can be seen in Table 1

Table 1

Research Design

\begin{tabular}{llrcc}
\hline & Group & Pre Test & Treatment & Post Test \\
\hline Random & A (Experiment Group) & O1 & X & O2 \\
Random & B (Control Group) & O3 & - & O4 \\
\hline
\end{tabular}

Source: Syaodih (2011: 204)

Information :

$\mathrm{X}$ : Learning with Group Investigation (GI) cooperative learning model

- : Conventional or ordinary learning

O1 : Pre-test experimental class

O2 : Post test experimental class

O3 : Pre-test control class

O4 : Control class post test

The data collection instruments used in this study are as follows:

1. Observation

Observation is used when looking at the school environment for the first time and to observe researchers doing learning using the Group Investigation (GI) cooperative learning model.

\section{Documentation}

Documentation is used to find out the history of the school, the condition of teachers and students, facilities and infrastructure in the school.

3. Test

The test is used to determine the level of understanding of students' mathematical concepts.

There are 2 data analysis in this study, namely:

1. Early Stage Analysis

Before the sample is given treatment, it needs to be analyzed first through the normality test and homogeneity test. This is done to find out whether the two sample groups come from the same initial conditions. The data used in the early-stage analysis came from the pre-test scores are normality test and homogeneity Test

2. Final Stage Analysis

a. Hypothesis testing

The final stage of analysis is an analysis to test the research hypothesis using hypothesis testing after the two samples were given different treatments. Before testing the 
hypothesis, the analysis prerequisites are tested, namely: normality test, homogeneity test, and hypothesis test

b. Observation sheet analysis

This analysis is used to obtain information about the learning management process using the Group Investigation (GI) cooperative learning model in the experimental class.

\section{RESULTS AND DISCUSSION}

The implementation of this research was carried out on September 30, 2021 until October 11, 2021 in class VII C and VIII D at SMP Negeri 3 Pekanbaru. In this study, two classes were used, namely VII C as an experimental class using a Group Investigation (GI) cooperative learning model and class VII D as a control class using a conventional learning model.

This research was conducted in six meetings with four lessons and two tests (pre-test and post-test). The pre test was carried out at the first meeting with square and rectangular material and the post test was carried out at the last meeting with cube and block material.

The data description of the post test results of students' mathematical concept understanding ability obtained is described according to the highest value (Xmax), the lowest value (Xmin), average and standard deviation $(\mathrm{S})$ which are presented in table 2:

Table 2

Post Test Results of Students' Mathematical Concept Understanding Ability in Experiment Class and Control Class

\begin{tabular}{ccc}
\hline Statistic & \multicolumn{2}{c}{ Grade } \\
\cline { 2 - 3 } $\boldsymbol{N}$ & Experiment & Control \\
$\sum \boldsymbol{x}$ & 20 & 22 \\
$\overline{\boldsymbol{x}}$ & 1588,75 & 1421,25 \\
$\boldsymbol{x}_{\text {maks }}$ & 79,43 & 64,60 \\
$\boldsymbol{x}_{\text {min }}$ & 100 & 90 \\
$\boldsymbol{S}$ & 50 & 40 \\
Ideal Score & 13,99 & 13,97 \\
\hline
\end{tabular}

Based on table 2, it can be seen that the average value of the ability to understand mathematical concepts of students who study with the Group Investigation (GI) cooperative learning model is 79.43 which is higher than the average value of the ability to understand mathematical concepts of students who study with conventional learning models, namely 64.60. Based on the standard deviation data (S) the ability to understand mathematical concepts of students who study with the Group Investigation (GI) type cooperative learning model, which is 13.99 , is more spread out than the standard deviation data studied by conventional learning, which is 13.97. learning with cooperative learning model type Group Investigation (GI) is higher than students who learn with conventional learning. This shows that the value of students' ability to understand mathematical concepts in the experimental class is away from the average value, that is, there is a big difference between students who get high scores and students who get low scores. The maximum value of students' ability to understand mathematical concepts for the experimental class is 100, which is higher than the control class, which is 90 , while the minimum value for the experimental class is 50 , which is higher than the control class, which is 40 . 
Before testing the statistical hypothesis, the analysis requirements were first tested, namely the data from the post-test results of students' mathematical concept understanding abilities who studied with the Group Investigation (GI) cooperative learning model in the experimental class and the control class. Test requirements analysis is a test of normality and homogeneity test.

\section{Normality Test}

Normality test is used to determine the two samples come from a population of data that is normally distributed. The normality test of the post-test value of the ability to understand mathematical concepts of experimental class students and control class students was carried out using the Lilifors test at a significant level of $=0.05$ the results can be seen in table 3 .

Table 3

Normality Test Data Post Test Ability to Understand Mathematical Concepts Students of Experiment Class and Control Class

\begin{tabular}{ccc}
\hline \multirow{2}{*}{ Count } & \multicolumn{2}{c}{ Grade } \\
\cline { 2 - 3 } $\boldsymbol{L}_{\text {count }}$ & Experiment & Control \\
$\boldsymbol{L}_{\text {table }}$ & 0,0725 & 0,0899 \\
Information & 0,190 & $2^{0,1}$ \\
& Normal & Normal
\end{tabular}

Based on the results of the normality test in table 3, it is obtained L_count $<$ L_table, so it can be concluded that the ability to understand mathematical concepts of students in the experimental class and control class is normally distributed.

2. Homogeneity Test

The homogeneity test of the post-test value of the ability to understand mathematical concepts of experimental class students and control class students was carried out by the F-test, which was to divide the largest variance with the smallest variance. The results of the homogeneity test calculation on the ability to understand mathematical concepts of experimental class students at a significant level $=0.05$ can be seen in table 4 .

Table 4

Homogeneity Test Post Test of Mathematical

Concept Understanding Ability of Experiment Class and Control Class Students

\begin{tabular}{ccccc}
\hline $\begin{array}{c}\text { Concept } \\
\text { Understanding }\end{array}$ & Grade & $\begin{array}{c}\text { Variance } \\
\left(\boldsymbol{S}^{\mathbf{2}}\right)\end{array}$ & $\boldsymbol{F}_{\text {count }}$ & $\boldsymbol{F}_{\text {table }}$ \\
\cline { 2 - 4 } & Experiment & 195,30 & 1,00 & \\
\cline { 2 - 4 } & Control & 195,29 & & \\
\hline
\end{tabular}

Based on the results of the homogeneity test in table $4, F_{-}$count $\leq F$ table is obtained, so it can be concluded that the students' ability to understand mathematical concepts in the experimental class and control class has a homogeneous variance.

The results of the analysis requirement test showed that the data group of students' ability to understand mathematical concepts in the experimental class and control class was normally distributed and homogeneous. The results of the calculation of the hypothesis test according to Hartono (2010: 208) can be seen in table 5. 
Table 5

Calculation Results for Hypothesis Testing

\begin{tabular}{|c|c|c|}
\hline \multirow[t]{2}{*}{ Statistic } & \multicolumn{2}{|c|}{ Concept Understanding } \\
\hline & $\begin{array}{l}\text { Experiment } \\
\text { (A1) }\end{array}$ & $\begin{array}{l}\text { Control } \\
\text { (A2) }\end{array}$ \\
\hline$N$ & 20 & 22 \\
\hline $\bar{x}$ & 79,43 & 64,60 \\
\hline$S^{2}$ & 13,99 & 13,97 \\
\hline$t_{\text {count }}$ & \multicolumn{2}{|c|}{3,34} \\
\hline$t_{\text {table }}$ & \multicolumn{2}{|c|}{2,02} \\
\hline
\end{tabular}

Based on the results of hypothesis testing at a significant level of $=0.05$, the value of $\mathrm{t} \_$table $=2.02$ is obtained. When compared with $\mathrm{t} \_$hitung=3.34 so $\mathrm{t} \_$count $>\mathrm{t} \_t a b l e$, it can be concluded that Ha is accepted, meaning that there is a significant influence between the ability to understand mathematical concepts of students who learn to use the Group Investigation type cooperative learning model and students who learn to use conventional learning at SMP Negeri 3 Pekanbaru. This means that the results of this analysis indicate that there is a significant effect between the ability to understand mathematical concepts of students who learn to use the Group Investigation (GI) cooperative learning model and students who learn to use conventional learning in class VII of SMP Negeri 3 Pekanbaru.

The results of this study also support the previous research conducted by Misrayanti in her thesis entitled Research on the effect of the application of the Group Investigation learning model on understanding mathematical concepts in terms of the initial mathematical abilities of Madrasah Tsanawiyah students. The results of the calculation of the " $t$ " test obtained tcount = 1.778 and ttable $=1.67$. The $\mathrm{t}$-count compared to $\mathrm{t}$-table at a significant rate of $5 \%$ is $1.778>1.67$ or tcount $>$ ttable. This shows that there is a difference in the ability to understand mathematical concepts of students who learn to use the Group Investigation learning model compared to students who learn to use conventional learning.

Thus the results of this analysis support the formulation of the problem proposed, namely whether there is a significant influence on the ability to understand mathematical concepts between students who learn to use the Group Investigation learning model and students who learn to use conventional learning at SMP Negeri 3 Pekanbaru. This is in accordance with the theory in chapter II that group investigations are discoveries made in groups, students in groups experience and experiment actively which allows them to find principles (Slavin, 2008: 216). In this type of learning model, students are involved in identifying the topics to be studied, study planning, material investigation, material presentation and learning evaluation. Based on steps like this, it will make it easier for students to prepare themselves in learning because students not only act as recipients of material but also as investigators and presenters of material. Directly or indirectly, the ability to understand students' mathematical concepts will increase because this type of Group Investigation confronts students together to problems which are then directed to the discovery of concepts or principles and how to deliver them so that the concept is expected to be well embedded which in the end students have excellent comprehension skills. 


\section{CONCLUSION}

Based on the results of the analysis, there is a significant effect between the ability to understand mathematical concepts of students who learn to use the Group Investigation (GI) cooperative learning model and students who learn to use conventional learning at SMP Negeri 1 Kuok. The results of the calculation of the " $t$ " test obtained t_hitung $=3.34$, with $=0.05$ and dk $=40$ from the distribution list $\mathrm{t}$ obtained $\mathrm{t} \_$table $=2.02$. It can be seen from the value of tcount $>$ ttable, it can be concluded that Ha is accepted and Ho is rejected.

The average value of the experimental class is 79.43 which is higher than the average value of the control class, which is 64.60. It means that the average value of the experimental class is better than the average value of the control class. Thus, there is a positive effect of the application of the Group Investigation (GI) cooperative learning model on the ability to understand mathematical concepts of SMP Negeri 3 Pekanbaru. While the average teacher activity in implementing learning using the Group Investigation (GI) cooperative learning model on students' mathematical concept understanding ability is $94.1 \%$ and the average student learning activity using Group Investigation (GI) cooperative learning model on understanding ability $90.4 \%$ of students' mathematical concepts in SMP Negeri 3 Pekanbaru.

\section{REFERENCES}

Joyce, B., Weil, M. and Calhoun, E. (2003). Models of Teaching Centers for Teaching and Technology Book Library.96

Hamalik, O. (2008). Perencanaan Pengajaran Berdasarkan Pendekatan Sistem. Jakarta: Bumi Aksara.

Hamdani. (2011). Strategi Belajar Mengajar. Bandung: CV Pustaka Setia.

Heris Hendriana, dkk. (2017). Hard Skills dan Soft Skills Matematika Siswa. Bandung: PT Refika Aditama.

Sharan, S., Sharan, Y., \& Tan, I. G.-C. (2013). The group investigation approach to cooperative learning.

Slavin, R. E. (2009). Cooperative Learning. Bandung: Nusa Media.

Sukmadinata, N. S. (2011). Metode Penelitian Pendidikan. Bandung: PT Remaja Rosdakarya. 